interactions. They pointed out that there had been no experiment thus far to prove or disprove the validity of the parity law for this class of physical interactions, and suggested a number of possible tests. Early in 1957, in collaboration with scientists at tho National Bureau of Standards, Dr. Wu announced the results of the first such experiment which established that parity was, in fact, violated in weak interactions.

The Public Welfare Medal has been awarded to Dr. Detlev W. Bronk, president of the National Academy of Sciences from 1950 until 1962, for his "eminence in the application of seience to the public welfare". Dr. Bronk holds a unique position in educational and scientific leadership in the United States. While presiding over the affairs of the Rockefeller Institute and transforming it from a purely research centre to a fully fledged graduate university, he served simultaneously as president of the Academy, official adviser on science and technology to the Federal Government; chairman of the National Science Board, which establishes policy for the National Science Foundation; and a member of the President's Science Advisory Committee, the National Aeronautics and Space Council, and the Defense Science Board. At the same time, he served as trustee of Johns Hopkins University, University of Pennsylvania, Bucknell University, the Rockefeller Foundation, the Rockefeller Brothers Fund, and many other institutions.

\section{Foreign Associates}

THE following have been appointed foreign associates of the Academy: Sir Christopher Andrewes, former deputy director of the National Institutes for Medical Research, London; Prof. J. B. S. Haldano, research professor, Genetics and Biometry Laboratory, Orissa; Sir Hans Krebs, ehairman of the Department of Biochemistry at the University of Oxford; Prof. H. G. Lundegardh, professor emeritus at the College of Agriculture of Sweden and director of the Research Laboratory in Plant Physiology, Penningby; Prof. M. G. J. Minnaert, professor emeritus at the University of Utrecht and, during the past year, director of the Utrecht Observatory; Prof. M. Roy, directeur général de l'Office National d'Etudes et de Recherches Aéronautiques.

\section{Director of Materials and Structures Research and Development at the Ministry of Aviation :}

Dr. N. J. L. Megson, C.B.E.

DR. N. J. L. MEgson, director of materials and structures research and development in the Ministry of Aviation, retired from the Public Service on November 16, 1963. Dr. Megson, who was born in 1903, graduated. in chemistry at the University of Birmingham, gaining his B.Se. in 1924 and M.Se. in 1925. The degree of doctor of science was conferred on him in 1946. Dr. Megson entered the Scientific Civil Service in 1927 as a research chemist with the Department of Scientific and Industrial Research, and served at the Chemical Research Laboratory, Teddington, where he was in charge of the section dealing with synthetic resins. In 1939 he became a scientific officer and was seconded to the Ministry of Supply (later the Ministry of Aviation) as adviser on plastics. Later he was in charge of the Advisory Service on Plastics, Rubber and Paints. Dr. Megson was promoted to senior scientific officer in 1940 , to principal scientific officer in 1944, and in 1951 he was promoted to senior principal scientific officer and appointed superintendent (Chemistry Department) at the Royal Aircraft Establishment. He remained there until 1959 when he was promoted to deputy chief scientific officer and appointed to the post which he held at the date of his retirement.

\section{Mr. E. W. Russell}

Mr. F. W. Russell has been appointed director of materials and structures research and development in the
Ministry of Aviation, in succession to Dr. N. J. L. Megson. Mr. Russell, who is fifty, was educated at Westminster City School and afterwards graduated with an external London degree in chemistry, physics and mathematics. He joined the Chemistry Department of the Royal Aircraft Establishment in 1936 as an assistant, where he worked on a wide range of topics including oil oxidation, the fire-proofing of textiles and the detection of carbon monoxide. He was promoted to scientific officer in 1942 , to senior scientific officer in 1945 and to principal scientific officer in 1948. During this period his interests in polymer research were stimulated by a study on the spot of the extensive U.S. Government sponsored effort. In pursuit of these interests he studied various aspects of the applications of non-metallic materials in aircraft and published papers on transparent plastic materials and on the erystallization at low temperatures of natural rubber vulcanizates. He was promoted in 1955 to senior principal scientific officer when he became superintendent of the Non-Metallic Materials Division concerned with all aspects of polymer work from micro-evaluation to plastic structures.

\section{U.S. National Academy of Engineering}

Puans have been drawn up by a Committee appointed by Dr. Frederick Seitz, president of the U.S. National Academy of Seiences, to consider the formation of a U.S. National Academy of Engineering. The Committee, which will seek a Congressional charter for the proposed academy, has elected three officers: Dr. A. B. Kinzel, vice-president for research, Union Carbide Corporation, Chairman; Dr. E. A. Walker, president, the Pennsylvania State University, Vice-chairman; and Dr. H. K. Work, director of the Research Division and associate dean, School of Engineering and Science, New York University, Executive Secretary. Sub-committees have been set up to deal with the main tasks of organizing the new Academy. With the aid of these sub-committees, the Committee will critically review the proposed organization of the National Academy of Engineering, secure a charter and select additional charter members. It is anticipated that the National Academy of Engineering will be a private non-profit organization dedicated to the furtherance of engineering in the common interest serving the nation in connexion with problems in engineering and technology. The preliminary objectives of the Academy as envisaged at present are: (1) to formulate programmes for the effective use of the resources of the United States; (2) to explore means for promoting co-operation in engineering in the United States and abroad in order to secure concentration of effort on significant engineering problems; (3) to encourage the interaction of engineering with the physical sciences, the medical sciences, and the social sciences in support of the more effective application of technology; (4) to sponsor such engineering research as may be advisable in the national interest; (5) to offer its services and make its findings available to the Government; (6) to advise the Government on national policy matters pertinent to engineering.

\section{Higher Education in India}

ThE report for the year 1962-63 of the University Grants Commission, New Delhi, records a $10 \cdot 15$ per cent increase on 1961-62 in the enrolment of students, to $1,272,666$, and compared with 651,479 in $1954-55$, the number of universities inereasing to 55 ; nearly 85 per cont of the enrolment was in colleges, the number of which increased by 129 (Pp. iii +58 . Now Delhi: University Grants Commission. Available from Manager of Publications, 1964 . Rs. $1.60 ; 3 s .9 d . ; 0.58$ dollars). The total number of teachers in universities and colleges was 66,370 , but there is an acute shortage of competent and experienced teachers in certain fields. The Commission stresses the importance of raising the standards main- 